\title{
CATEGORISATION OF FINE NEEDLE ASPIRATES OF THYROID ACCORDING TO THE BETHESDA SYSTEM FOR REPORTING THYROID CYTOPATHOLOGY AND HISTOLOGIC CORRELATION
}

\author{
Shwetha Jose *1, Jinu Abraham ${ }^{2}$.
}

${ }^{* 1}$ Assistant Professor of Pathology, Al Azhar Medical College and Super specialty Hospital, Ezhalloor Road, Thodupuzha, Idukki, Kerala, India.

2 Assistant Professor of Pathology, Sree Gokulam Medical College and Research foundation, Venjaramoodu Trivandrum, 695607, Kerala, India.

\section{ABSTRACT}

Background: Fine-needle aspiration (FNA) is the procedure of choice in the preoperative evaluation of thyroid nodules. But it suffers as a modality both because of variability in its diagnostic terminology. The 2007 National Cancer Institute Thyroid Fine-Needle Aspiration Conference helped instigate the recent publication of The Bethesda System for Reporting Thyroid Cytopathology. The objective of this study was to report our experience in using this new reporting system to review the distribution of diagnostic categories and to evaluate the specificity of the system based on the cytologic-histologic correlation.

Materials and Methods: The study was done in Yenepoya Medical College, Deralakatte, Mangalore, Karnataka during the two year period from May 2010 to April 2012. 200 patients with thyroid enlargement were included in the study. FNA of the thyroid gland was done using a 23-guage needle and smears were prepared which were stained and studied under light microscope. The cytologic findings were categorized under The Bethesda System. Histologic correlation was done wherever possible.

Results: The distribution of categories from 200 evaluated nodules was as follows: $12.5 \%$ unsatisfactory (I), $79.5 \%$ benign (II), $0.5 \%$ atypia of undetermined significance (III), $3 \%$ follicular neoplasm or suspicious for follicular neoplasm (IV), $2 \%$ suspicious for malignancy (V), and $2.5 \%$ malignant (VI). The specificity for diagnosing neoplastic thyroid nodules was $97 \%$ and the overall diagnostic accuracy of FNAC was $88.095 \%$. The malignancy risk for categories $\mathrm{V}$ and $\mathrm{VI}$ is $100 \%$.

Conclusion: These data demonstrate that the new classification system is excellent for reporting thyroid FNAs. Application of this nomenclature will lead to less ambiguity in diagnosis and consistent therapeutic approach. KEY WORDS: Thyroid cytopathology, The Bethesda System.

Address for correspondence: Dr. Shwetha Jose, Assistant Professor (Pathology), Al Azhar Medical College and Super specialty Hospital, Ezhalloor Road, Thodupuzha Distt. - Idukki, Kerala, India. Pin-685584, Phone-+918111845287 E-Mail: docscholar.dr@gmail.com

\begin{tabular}{|c|c|c|}
\hline \multicolumn{3}{|c|}{ Online Access and Article Informtaion } \\
\hline \multirow{2}{*}{$\begin{array}{l}\text { Quick Response code } \\
\text { DOI: } 10.16965 / \text { ijims.2017.122 }\end{array}$} & \multicolumn{2}{|c|}{$\begin{array}{l}\text { International Journal of Integrative Medical Sciences } \\
\qquad \text { www.imedsciences.com }\end{array}$} \\
\hline & $\begin{array}{l}\text { Received: 19-12-2017 } \\
\text { Reviewed: 19-12-2017 }\end{array}$ & $\begin{array}{l}\text { Accepted: 08-01-2018 } \\
\text { Published: 31-01-2018 }\end{array}$ \\
\hline Source of Funding: Self & \multicolumn{2}{|c|}{ Conflicts of interest: None } \\
\hline
\end{tabular}

\section{BACKGROUND}

The main purpose of thyroid FNA is to distinguish between patients with malignancy or possible malignancy, thyroid lesions requiring surgical treatment and those with benign nodules that can be followed up clinically or treated medic- ally. It is therefore important that the cytopathologist communicate thyroid FNA interpretations to the referring physician in terms that are unambiguous and clinically useful [1].

The recently introduced Bethesda System for Reporting Thyroid Cytopathology (TBSRTC) has 
standardized our diagnostic approach to reporting and cytomorphological criteria. TBSRTC has offered 6 diagnostic categories for the reporting of thyroid FNAs. Recently published data supports the clinical utility \& wide acceptance of TBSRTC by both practicing pathologists and clinicians. Thyroid association devised its clinical guidelines for the management of patients and TBSRTC offers a useful source of information for pathologists as well [1].

The objective of this study is to report our experience in using this new reporting system to distribute the 6 diagnostic categories of The Bethesda System and to evaluate the specificity of the system based on the cytologic - histologic correlation.

The aims and objectives of our study were,

1.To report our experience using The Bethesda System of Reporting of Thyroid FNA and review the distribution of diagnostic categories.

To correlate cytologic diagnosis with histopathological study wherever possible and obtain cyto-histopathological correlation and assess the sensitivity and specificity of FNA.

\section{MATERIALS AND METHODS}

200 patients who came with thyroid enlargement and underwent FNA procedure were included in our study. The fine needle aspiration was done by cytopathologist and the smears were stained by Papanicolaou and Giemsa and studied. The samples were retrospectively collected and reviewed and categorised by a cytopathologist as per the Bethesda nomenclature.

Diagnostic categories of Bethesda System:

Non diagnostic or unsatisfactory: All the smears which did not comply with the adequacy criteria laid down by the Bethesda system were included in this category. All the smears which contained a minimum of six well visualised and well preserved groups of follicular cells were considered adequate [1]. Smears containing only cyst fluid with macrophages and no follicular cells fell in this category. However, smears containing cytological atypia did not require a minimum number of follicular cells.

Benign Follicular nodule: Smears with an adequate number of follicular cells and showing features of colloid or nodular goiter, lymphocytic thyroiditis, hyperplastic nodule, granulomatous thyroiditis were categorised in this section [1].

Atypia of undetermined significance (AUS): Aspirates which were adequate an showed features of atypia but could not be classified under categories II,IV,IV,V or VI were grouped under this category. ${ }^{2}$ One example is a paucicellular aspirate showing a predominant population of microfollicles against a background of scant colloid. Another example is the presence of focal nuclear features suggestive of papillary carcinoma in an otherwise benign appearing sample [1].

Follicular neoplasm / Suspicious for a follicular neoplasm: Cellular aspirates showing a predominant microfollicle distribution against scant or no colloid background were grouped in this category. Features suggestive of Hürthle cell neoplasm were also classified here [1]. [Fig 1]

Suspicious for malignancy: When some features of malignancy are present but are not sufficient for a definitive diagnosis, there were classified under this category. Patchy nuclear changes pattern are those where normal cells are admixed with cells having nuclear enlargement, grooving and irregularity. Another example is the presence of nuclear features of papillary carcinoma in a sparsely cellular aspirate [1].

Malignant: Smears having definitive features of malignancy were placed in this category. [Figure 2]

Histologic correlation: Out of the 200 cases of thyroid fine-needle aspirates collected during the two year period, histological data were available for 45 cases.

\section{RESULTS}

Out of the 200 cases, category II (benign) constituted the major bulk which constituted 79.5\%. Category I ("Inadequate") consisted of $12.5 \%$ of the 200 cases. Category III, IV, V and VI consisted of $0.5 \%, 3 \%, 2 \%$ and $2.5 \%$ of the 200 cases respectively. The adequacy rate of obtained in the present study was $87 \%$.

Out of the 200 cases of thyroid fine-needle aspirates collected during the two year period, 45 patients underwent thyroidectomy in our 
Table 1: comparison of FNA diagnosis with subsequent histological diagnosis.

\begin{tabular}{|c|c|c|c|c|c|c|}
\hline \multirow{2}{*}{ FNA- Bethesda Category } & \multirow{2}{*}{$\begin{array}{c}\text { HP data } \\
\text { available }\end{array}$} & \multicolumn{5}{|c|}{ Histological Diagnosis } \\
\cline { 3 - 8 } & $\begin{array}{c}\text { Colloid/Nodular } \\
\text { Goitre }\end{array}$ & $\begin{array}{c}\text { Hashimoto's } \\
\text { Thyroiditis }\end{array}$ & $\begin{array}{c}\text { Follicular cell } \\
\text { neoplasm }\end{array}$ & $\begin{array}{c}\text { Hurthle cell } \\
\text { neoplasm }\end{array}$ & $\begin{array}{c}\text { Papillary } \\
\text { Carcinoma }\end{array}$ \\
\hline Scanty & $\mathbf{3 / 2 5}$ & 2 & - & - & - & 1 \\
\hline "Benign" & $36 / 159$ & 28 & 4 & - & 1 & 3 \\
\hline "AUS" & $1 / 1$ & 1 & - & - & - & - \\
\hline "Suspicious for FN" & $1 / 6$ & - & - & 1 & - & - \\
\hline $\begin{array}{c}\text { "Suspicious for } \\
\text { malignancy" }\end{array}$ & $\mathbf{2 / 4}$ & - & - & - & - & 2 \\
\hline "Malignant" & $\mathbf{2 / 5}$ & - & - & - & - & 2 \\
\hline TOTAL & $\mathbf{4 5 / 2 0 0}$ & $\mathbf{3 1}$ & $\mathbf{4}$ & $\mathbf{2}$ & $\mathbf{1}$ & $\mathbf{8}$ \\
\hline
\end{tabular}

hospital. The FNA diagnoses and subsequent histopathologic diagnoses were compared [Table 1]. From this, the malignancy risk was calculated for each category. The malignancy risk was $100 \%$ for the categories $\mathrm{V}$ and $\mathrm{VI}$ according to the present study. The malignancy risk of category I was $33.3 \%$ and that of category II was $8.3 \%$.

Fig. 1: predominant microfollicle distribution against scant or no colloid background suggestive of Follicular neoplasm.

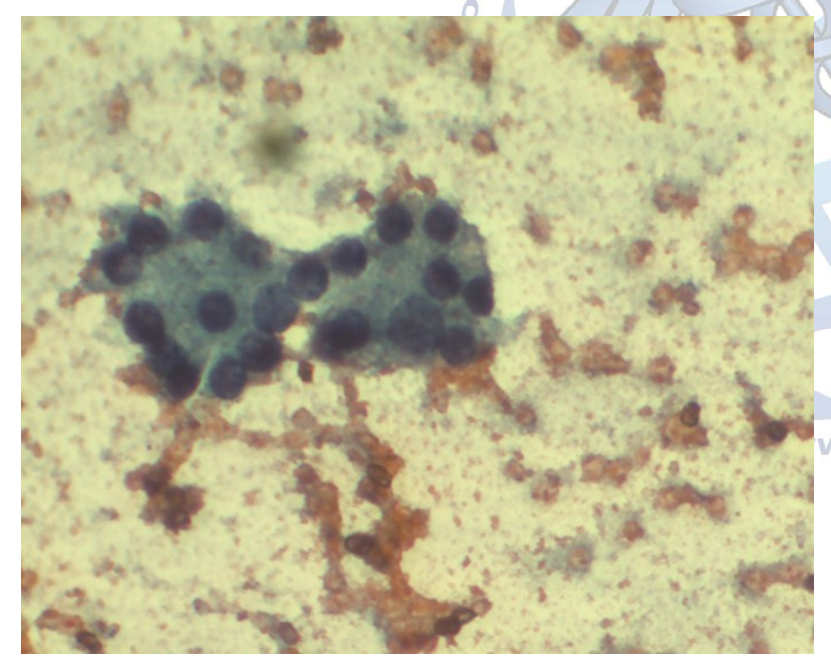

Fig. 2: Smear of Malignant lesion (High cellularity, crowded irregular follicles, Large pleomorphic nuclei, abnormal chromatin).

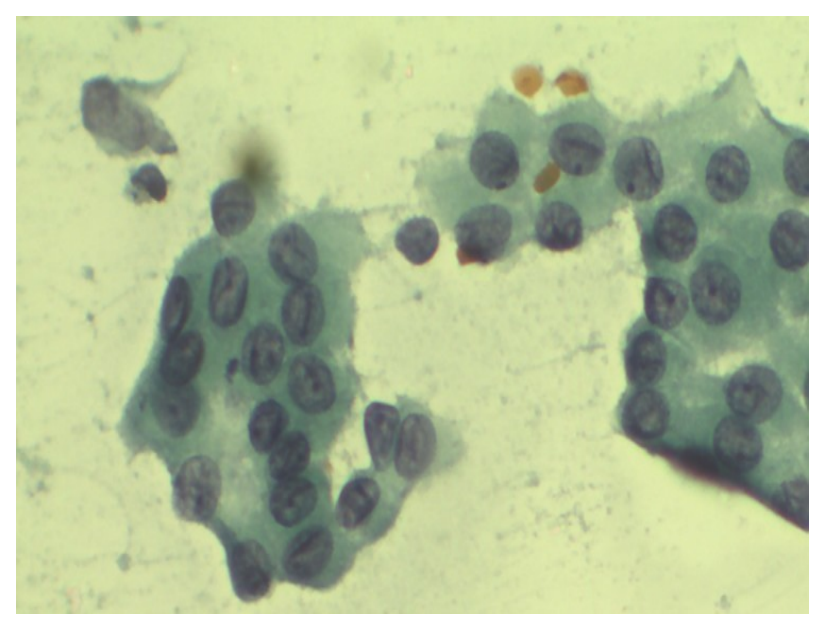

In our study, classification of FNAs of thyroid lesions according to the proposed standardized nomenclature yields comparable results in categories $\mathrm{V}$ and $\mathrm{VI}$ for risk of malignancy reported by others.

The malignancy rate of AUS category was nil because the only single case was proved to be multinodular goiter with adenomatous nodule on histology. The malignancy rate for follicular neoplasm was nil because out of the five cases, histological correlation was available only for one case and it turned out to be adenoma on histology.

The incomparable malignancy rate was due to the paucity of histological follow-up data available in the present study and the small sample size.

From the histological and cytological data, the true positives, true negatives, false positives and false negatives were identified. Sensitivity, specificity, positive predictive value and negative predictive value were calculated and were $55.55 \%, 97 \%, 83.33 \%$ and $88.9 \%$ respectively.

\section{DISCUSSION}

The current study attempted to report thyroid fine needle aspirates according to the recently proposed six-tier diagnostic classification system.

The adequacy rate in the thyroid aspirate is low compared to other organs. The rate of nondiagnostic smears may be influenced by the nature of the thyroid nodules, the experience of the aspirators, whether on site adequacy assessment is performed, and the criteria used to define specimen adequacy. The adequacy rate of the fine-needle aspirates in the present study 
was $87 \%$ and it was comparable to studies by Handa $U$ et al [3] (94.9\%) and Guhamallaick M et al [4] (86\%) and higher than that obtained by Tabaqchali et al [5] (67.8\%). The incidence of the various Bethesda categories of the present study was comparable to that of similar studies which followed the same system for reporting $[6,7]$.

In our study, classification of FNAs of thyroid lesions according to the proposed standardized nomenclature yields comparable results in cateogories $\mathrm{V}$ and $\mathrm{VI}$ for risk of malignancy reported by others [6-8]. [Table.2]

Table 2: Risk of malignancy for various categories in different studies.

\begin{tabular}{|c|c|c|c|c|}
\hline Category & $\begin{array}{c}\text { Jo VY et al 2009 } \\
\text { [6] }\end{array}$ & $\begin{array}{c}\text { Theoharis et al } \\
\text { 2009 [7] }\end{array}$ & $\begin{array}{c}\text { Mondal et al } \\
\text { 2013 [8] }\end{array}$ & $\begin{array}{c}\text { Present } \\
\text { study }\end{array}$ \\
\hline I & $8.90 \%$ & - & 0 & $33.33 \%$ \\
\hline II & $1.10 \%$ & $9.80 \%$ & 4.5 & $8.30 \%$ \\
\hline III & $17 \%$ & $48 \%$ & 20 & - \\
\hline IV & $25.40 \%$ & $34 \%$ & & - \\
\hline V & $70 \%$ & $87 \%$ & $60-75$ & $100 \%$ \\
\hline VI & $98.10 \%$ & $100 \%$ & $97-99$ & $100 \%$ \\
\hline
\end{tabular}

However, the malignancy risks for categories I, II, III and IV were not comparable to the other studies due to the following reasons. The malignancy risk of AUS category was nil because the only single case was proved to be multinodular goiter with adenomatous nodule on histology. The malignancy rate for follicular neoplasm was nil because out of the five cases, histological correlation was available only for one case and it turned out to be an adenoma on histology.

Given the selection bias of only 36 patients diagnosed as benign undergoing surgery, sensitivity, false negative rate and negative predictive value could not be accurately calculated. The low sensitivity of the present study was due to this selection bias. This could also be due to the high false negative rate. Three of the cytologically diagnosed colloid goiter cases proved to be papillary carcinoma on histology and one cytologically diagnosed colloid goiter on histology was shown as Hürthle cell neoplasm. The false negative rate for papillary carcinoma in the present study was due to selection bias, sampling error, and the presence of micro papillary carcinoma.

\section{CONCLUSION}

Fine-needle aspiration has proven to be the most valuable diagnostic modality for preoperative distinction of benign from malignant nodules. The Bethesda System for Reporting Thyroid Cytopathology which was introduced in 2007 has standardized the diagnostic approach to reporting and cytomorphological criteria. If this standardized system is universally followed, it could lead to improved interlaboratory agreement and more consistent management approaches.

\section{REFERENCES}

[1]. Ali SZ, Cibas ES. The Bethesda System for Reporting Thyroid Cytopathology. New York: Springer; 2010.

[2]. Layfield LJ, Morton MJ, Cramer HM, Hirschowitz S. Implications of the proposed thyroid fine needle aspiration category of "follicular lesion of undetermined significance": A five year multi institutional analysis. Diagn Cytopathol 2009;37:710 4.

[3]. Handa U, Garg S, Mohan H, Nagarkar N. Role of fine needle aspiration cytology in diagnosis and management of thyroid lesions: A study on 434 patients. J Cytol. 2008;25(1):13-7.

[4]. Guhamallick M, Sengupta S, Bhattacharya NK, Basu $\mathrm{N}$, Roy $\mathrm{S}$, et al. Cytodiagnosis of thyroid lesionsusefulness and pitfalls: A study of 288 cases. J Cytol. 2008;25(1):6-9.

[5]. Guhamallick M, Sengupta S, Bhattacharya NK, Basu $\mathrm{N}$, Roy $\mathrm{S}$, et al. Cytodiagnosis of thyroid lesionsusefulness and pitfalls: A study of 288 cases. J Cytol. 2008;25(1):6-9.

[6]. Jo VY, Stelow EB, Dustin SM, Hanley KZ. Malignancy risk for fine-needle aspiration of thyroid lesions according to the Bethesda system for reporting thyroid cytopathology. Am J Clin Pathol. 2009;134:450-6.

[7]. Theoharis CG, Schofiled KM, Hammers L, Udelsman $\mathrm{R}$, Chhieng DC. The Bethesda thyroid fine-needle aspiration classification system: year 1 at an academic institution. Thyroid. 2009;19: 1215-23.

[8]. Mondal SK, Sinha S, Basak B, Roy DN,, Sinha SK. The Bethesda system for reporting thyroid fine needle aspirates: A cytologic study with histologic followup. J Cytol 2013;30:94-9.

How to cite this article: Shwetha Jose, Jinu Abraham. CATEGORISATION OF FINE NEEDLE ASPIRATES OF THYROID ACCORDING TO THE BETHESDA SYSTEM FOR REPORTING THYROID CYTOPATHOLOGY AND HISTOLOGIC CORRELATION. Int J Intg Med Sci 2018;5(1):561-564. DOI: 10.16965/ijims.2017.122 